\section{Færre barn med Downs syndrom}

I 2001 ga den nasjonale screeningkomité i Storbritannia råd om at alle gravide skulle tilbys screeningtest for Downs syndrom. Nå har engelske forskere studert utviklingen $i$ antall levendefødte barn med Downs syndrom i England og Wales i perioden 1989-2008 (1).

I denne 20-årsperioden økte antall prenatale og postnatale diagnoser av Downs syndrom med $71 \%$, mens antall levendefødte barn med syndromet falt med $1 \%$. Uten screening under svangerskapet ville antallet levendefødte ha økt med $48 \%$ - beregnet ut perioden. Hos mødre over 36 år med affiserte svangerskap lå andelen som var diayngre kvinner økte andelen fosterdiagnoser fra $3 \%$ til $43 \%$, et resultat av bedre tilgjengelighet og økt sensitivitet av testene. Hos kvinner med prenatal diagnose lå andelen som valgte svangerskapsavbrudd stabilt rundt $92 \%$.

- Disse funnene er ikke uventede, sier

\section{Bedre tilbud om prenatal diagnostikk har ført til færre levendefødte med Downs syndrom.} ifra mødrenes alder, som steg gjennom hele gnostisert prenatalt stabilt på $70 \%$. For assisterende avdelingsdirektør Kari Klungsøyr ved Medisinsk fødselsregister. - Totalforekomsten av Downs syndrom har økt i de fleste europeiske land pga. høyere alder hos de gravide, mens det rapporteres nedgang $\mathrm{i}$ antall affiserte levendefødte $\mathrm{i}$ takt med økt prenatal diagnostisering, sier hun.

- I Norge anbefales prenatal diagnostikk på indikasjon, f.eks. kvinnens alder. Også i Norge er det nedgang i andelen levendefødte barn med Downs syndrom, selv om vi er blant de landene der andelen er høyest. Som i England vil det i Norge fortsatt være mange affiserte svangerskap der diagnosen ikke blir stilt prenatalt eller der foreldrene ikke velger svangerskapsavbrudd. Utviklingen må følges nøye, ikke minst for fortsatt å sikre ressurser til dem som blir født med Downs syndrom, sier Klungsøyr.

\section{Trine B. Haugen \\ trine.b.haugen@hf.hio.no \\ Tidsskriftet}

\section{Litteratur}

1. Morris JK, Alberman E. Trends in Down's syndrome live births and antenatal diagnoses in England and Wales from 1989 to 2008: analysis of data from the National Down Syndrome Cytogenetic Register. BMJ 2009; 339: b3794.

\section{Stressede foreldre og astma hos barna}

\author{
Foreldrenes stressnivå kan \\ påvirke barnas sårbarhet for luft- \\ forurensning og dermed bidra \\ til utvikling av astma.
}

Trafikkrelatert forurensning gir trolig økt risiko for utvikling av astma hos barn. Det har dessuten vært diskutert om stress i hjemmet også kan påvirke barns sårbarhet for sykdommen. En amerikansk forskergruppe har nå forsøkt å undersøke dette (1).

Forskerne identifiserte 2497 barn i alderen 5-9 år uten astma. Foreldrenes selvopplevde stressnivå ble registrert ved bruk av validerte spørreskjemaer, i tillegg ble lokalt luftforurensningsnivå og hvorvidt mødrene hadde røykt under svangerskapet avdekket. Barna ble fulgt $i$ tre år. Der det var luftforurensning, var risikoen for å utvikle astma signifikant høyere hos dem hvis foreldre hadde høyt stressnivå.

- Astma hos barn kan deles inn i mange fenotyper med noe uklar avgrensning, sier professor Knut Øymar ved Barneavdelingen, Stavanger universitetssjukehus. - Mye tyder på at det er forskjellige risikofaktorer knyttet til utviklingen av ulike fenotyper. Denne forskergruppen ser ut til å være særlig opptatt av det man kan kalle bykjerneastma (inner city asthma). Dette er en ikke-atopisk form der risikoen er assosiert med forurensning og lav sosioøkonomisk status. Flere faktorer, bl.a. definisjonen av astma og hvilke aldersgrupper det dreier seg om, er viktig for resultatene. Overføringsverdien til alle former for astma og til norske forhold blir dermed usikker, sier han.

- Samvariasjon mellom et stort antall relaterte miljømessige faktorer gjør det vanskelig å trekke sikre konklusjoner om årsak og virkning. Studier som dette er likevel en påminnelse om at astmabehandling hos barn er langt mer enn det å skrive resept. Barnets miljø - i vid forstand - omfatter en rekke faktorer som bør tas med, sier Øymar.

\section{oeyhole@online.no \\ Medisinsk avdeling \\ Oslo universitetssykehus, Ullevål}

lingen av kvinner som ikke trenger behandling for sin egen helses skyld (dvs. har CD4-tall over 350 og ingen symptomer på immunsvikt) startes allerede i svangerskapsuke 14, mot uke 26-28 ifølge anbefalingene fra 2006. WHO angir to alternative regimer. Det ene er HAART-behandling (Highly Active AntiRetroviral Treatment) til mor fra uke 14 og hele ammeperioden. De tre medisinene tas fortrinnsvis som én enkelt kombinasjonstablett, noe som for-

\section{Litteratur}

1. World Health Organization. Rapid advise: use of antiretroviral drugs for treating pregnant women and preventing HIV infection in infants. www.who.int/hiv/pub/mtct/advice/en/index.html (30.11.2009).
Åslaug Helland

Tidsskriftet

\section{Litteratur}

Shankardass K, McConnell R, Jerrett $M$ et al. Parental stress increases the effect of traffic related air pollution on childhood asthma incidence. Proc Natl Acad Sci USA 2009; 106: $12406-11$. aslaug.helland@gmail.com 